\title{
An empirical model of issue evolution and partisan realignment in a multiparty system
}

Article

Accepted Version

Arndt, C. (2018) An empirical model of issue evolution and partisan realignment in a multiparty system. Political Research Quarterly, 71 (1). pp. 59-74. ISSN 1938-274X doi: https://doi.org/10.1177/1065912917722234 Available at https://centaur.reading.ac.uk/72607/

It is advisable to refer to the publisher's version if you intend to cite from the work. See Guidance on citing.

Published version at: http://journals.sagepub.com/doi/full/10.1177/1065912917722234

To link to this article DOI: http://dx.doi.org/10.1177/1065912917722234

Publisher: Sage

All outputs in CentAUR are protected by Intellectual Property Rights law, including copyright law. Copyright and IPR is retained by the creators or other copyright holders. Terms and conditions for use of this material are defined in the End User Agreement.

www.reading.ac.uk/centaur

\section{CentAUR}


Central Archive at the University of Reading

Reading's research outputs online 


\section{An Empirical Model of Issue Evolution and Partisan Realignment in a Multiparty System}

Christoph Arndt

Department of Political Science

Aarhus University

Bartholins Alle 7

8000 Aarhus C

Denmark

$\underline{\text { arndt @ps.au.dk }}$

+4587165615

\section{Keywords}

Issue evolution, realignment, immigration, multiparty system, elite polarization, issue salience

\section{Acknowledgements}

I thank the three reviewers and PRQ's editors for their highly valuable comments that helped me to improve the manuscript substantially. I also thank the participants of the workshop "Innovative research on public opinion and political behavior" at the NOPSA 2014, 12-15 August 2014, Gothenburg, and the participants of the Panel "Electoral Behaviour in Denmark" at the Annual Conference of Danish Political Science Association 2016, October 26-27, Hotel Vejlefjord especially Rune Stubager and Asmus Leth Olsen - for their valuable comments on previous versions of our manuscript.

\section{Funding}

This work was supported by The Danish Council for Independent Research - Project title:

"Investigating the Micro Foundation of Issue Voting and Issue Competition" under Grant Nr. 10093215. 


\begin{abstract}
Since Carmines and Stimson's seminal work, the concept of issue evolution has become a common theoretical toolkit to examine and explain polarization around cultural issues and partisan realignment in the U.S. However, very few studies outside the U.S. have applied the concept of issue evolution to explain electoral change and realignment around new issues at national elections over time. Analyzing whether and how Carmines and Stimson's concept travels to electoral change in a multiparty system would provide more theoretical leverage and create empirical knowledge on the logic of issue evolution outside the U.S and also whether the logic of electoral change differs from U.S-style two party systems. This article applies the issue evolution concept to a multidimensional multiparty system using micro-level data from 1971 to 2011 in combination with data on elite-level polarization to demonstrate that partisan realignment in Denmark follows an issue evolution process with niche parties as main drivers. Moreover, niche party polarization on the new dimension of conflict has a stronger effect on vote choice than mainstream party polarization.
\end{abstract}




\section{An Empirical Model of Issue Evolution and Partisan Realignment in a Multiparty System}

\section{Introduction}

Since Carmines and Stimson's seminal work (1986, 1989), the concept of issue evolution has become a commonly used theoretical toolkit to examine polarization around cultural issues and partisan realignment in the United States. Issue evolution occurs if a highly-salient new issue crosscuts the existing party alignment and then, after party elite polarization on the issue, the public reorganizes itself around the new cleavage. Political change and polarization in the United States since 1964 has followed an issue evolution process, with issues such as abortion, civil rights, race or religion leading to profound realignments among American voters (Adams 1997; Carmines and Stimson 1986, 1989; Layman 2001; Carmines and Woods 2002; Lindaman and Haidar-Markel 2002; Carsey and Layman 2006).

More recently, research has begun to apply the issue evolution concept to political change outside the United States (Stevens 2013 for the UK, Raymond and Feltch 2014 for Chile, and Stimson et al. 2012 for France). Most studies of issue evolution outside the United States, however, have been limited to other two party systems or the effect of Euroscepticism on vote choice in European Parliament elections. De Vries and Hobolt show that the impact of Euroscepticism on vote choice in European Parliament elections followed an issue evolution process as niche parties and losers of previous elections acted as issue entrepreneurs (De Vries and Hobolt 2012; Hobolt and De Vries 2015). Niche parties in particular, such as nationalists, greens or new right parties, induced an elite-level polarization on European integration, to which the mass public reacted by rewarding the niche parties' more Eurosceptical platforms.

Nevertheless, only Stevens' study provides a real cross-temporal examination of issue evolution and realignment using both micro-level data and data on elite polarization outside the U.S., which nevertheless excludes the Liberal Democrats and other third parties. Yet, we lack a thorough application of the issue evolution concept to a real multiparty system over time, which 
incorporates both the role of mainstream and new parties in the issue evolution process and their effects on voting behaviour and electoral change over time.

Consequently, this article applies the issue evolution concept to a multidimensional multiparty system using micro-level data from Denmark in the period 1971 to 2011 in combination with data on elite-level polarization. Denmark represents a European multiparty system, where cultural issues such as immigration, law and order, or the environment became more salient at the expense of economic issues (Green-Pedersen 2006, 2011; Stubager 2010; Arndt 2016). Furthermore, the balance of power has shifted substantially: until 1973, 90 percent of all governments were formed by the Social Democrats, while the majority of governments afterwards were formed by the centerright. In this respect, my contribution is fourfold. I first argue and demonstrate that only niche party polarization but not mainstream party polarization on the new dimension of conflict had significant effects on vote choice since 1971. Second, and in line with Carmines and Stimson's (1989) clarity and affect argument, I show that issue preferences on the new dimension of conflict had a stronger effect on party choice the more salient the new dimension had become on the elite level. Third, this effect is considerably stronger for the choice of niche parties than for the choice of mainstream parties. Lastly, models of voters' migration reveal that partisan realignment in Denmark followed an issue evolution process, where niche party polarization conditioned the effect of cultural conservatism on realigning with a right-wing party. In sum, the key finding is that issue evolution in a multiparty system in the sense of Carmines and Stimson is not driven by mainstream competitors, but by new and usually niche or challenger parties. 


\section{Issue Evolution and Partisan Realignment in Multiparty Systems}

Carmines and Stimson $(1986,1989)$ established the sequence of issue evolution in the United States, which starts with elite polarization on a new issue dimension and ends with mass partisan realignment. Clarity and affect provide two intervening steps in this causal chain. Clarity means that partisans have become aware of the increasing elite polarization on the new dimension. Affect means the electorate has reacted to the increasing elite polarization: "The public must not only perceive a difference in party issue stands, but must also care about this difference" (Carmines and Stimson 1989: 161). If these steps are fulfilled voters' mass realignment is the ultimate consequence.

Carmines and Stimson's sequence of issue evolution has been widely applied in explaining political change in the U.S. since the nomination of Barry Goldwater as GOP candidate in 1964. Various contributions have shown that cultural issues such as civil rights, race or religion have led to profound realignments among American voters. After deliberate polarization of new issues by political elites, the public showed strong reactions and finally changed party affiliations, shifting the balance of power to the benefit of the Republican Party in the post-1968 party system (Adams 1997; Carmines and Stimson 1986, 1989; Layman 2001; Lindaman and Haidar-Markel 2002; Carsey and Layman 2006). At the same time, Lindaman and Haidar-Markel (2002) identified examples in which elite polarization failed to produce an issue evolution due to insufficient reactions at the mass level. This relates to the nature of the issue since issues that are 'easy', in the sense that voters can easily understand their meaning, the elite framing around them, and the conflicting positions, have the potential to induce an issue evolution, whereas too technical issues will fail to do so (Carmines \& Stimson 1989: 11-12; Carmines 1991).

While Carmines and Stimson developed their theory for a pure two-party system with the very rare emergence and success of third parties or independents, an analysis of issue evolution in a multiparty system must incorporate more than two parties. The most important difference is the 
presence of niche (or new) parties who have different incentives to compete and create polarization over new issue dimensions.

The goal here is not to engage in an extensive debate about niche party definition and conceptualization. Rather, I follow one crucial defining criterion of niche parties, namely that they predominantly compete on a new issue dimension neglected by their mainstream competitors (Bischof 2015). This definition concerns green, nationalist, new right, and some radical left parties for the purpose of this paper. I further assume in line with Bischof's (2015: 5) review of the literature that niche parties at least in their early phase of existence attempt "to construct novel conflict lines from the periphery of party systems on issues with less competition", and that they in contrast to mainstream parties act as first movers.

In a two-party system, the losing mainstream party has an incentive to compete on new issues, especially if it has lost elections consecutively and it is clear that the current alignments within the electorate provide a structural disadvantage for the party (Riker 1982; Carmines 1991). It can therefore try to expand its electoral base by competing on new issues which potentially divide the opponent's electorate to regain votes and office. This is different under multiparty competition, where mainstream parties such as Conservatives, Christian Democrats, Liberals, and Social Democrats can still govern as long as their position on the established issue dimension permits coalitions with other mainstream parties, provided no party has a structural majority in the electorate.

Competing on a new dimension, however, has two caveats for mainstream parties under multiparty competition. First, policy-makers face constraints in turning to new issues after lost elections if the traditional dimension of conflict is strongly linked to existing partisan alignments (Carmines 1991: 67). This constraint is much stronger for losing mainstream parties since their leadership has usually been used to win elections under the traditional issue agenda or tried to win elections based on issue avoidance but not issue evolution. Under such circumstances, it is difficult 
to change the losing mainstream party's issue agenda by issue entrepreneurs and activists since the old elite still might get some benefits by sticking to the traditional issue agenda (Carmines 1991: 75-76). This constraint is not so vivid for new and niche parties, where issue entrepreneurs and activists can easily join and bring forward issues that disrupt the existing alignments. Moreover, the party organization can be build up around the new dimension of conflict from the early beginning. A related point is that mainstream parties in multiparty systems are generally more risk-averse and face stronger external and internal constraints in quickly adapting their strategies and positions to new (emerging) issue dimensions (Van de Wardt 2015; Kriesi et al. 2008: 14-18).

This means that mainstream parties in multiparty systems are confronted with a different incentive structure in changing its issue agenda, and we should expect niche parties to be the first mover as the latter faces fewer constraints in adapting its agenda (see Bischof 2015). Losing mainstream parties and their elites try in this respect first to win office and votes on the traditional issue agenda/dimension in the first rounds of competition and then steadily adapt after a niche competitor has proven that the new dimension potentially split the winner's/majority's electoral coalition (Arndt 2016). This further implies that office-seeking on the traditional dimension has failed several times and some traditional voters have gone anyway and new voters joined the niche party that opened the new dimension of conflict (thus a modified sequence of Carmines' argument on the decay of alignments in the U.S.). Moreover, losing mainstream parties in two-party systems can try to split the opponent's electoral coalition, and only face a non-voter tradeoff if they do, while opening a new dimension of competition by a mainstream party under multiparty competition yields less clear payoffs in the beginning. In the worst case, such a strategy could create niches for new competitors or increase the electoral potential of already existent niche party competitors who benefit from the increasing salience of their issues, while the electoral benefits for the mainstream party remain unclear in the first place. 
Second, and a by-product of the first constraint, a mainstream party can endanger its coalition potential under multiparty competition in the beginning if the new dimension represents a wedge issue with other established parties, irrespective of whether the new dimension might be electorally beneficial for the mainstream party (see Van de Wardt et al. 2014). Accordingly, issue polarization is induced by niche parties who usually have vote-seeking as their primary goal in the early phase of their existence and not coalition formation with established parties. Therefore, niche parties seek to exploit a first-mover advantage to establish a core constituency, which the established mainstream parties already have (Meyer and Wagner 2013; Bischof 2015).

In sum, mainstream parties in multiparty systems have different incentives to engage in issue evolution compared to their counterparts in two-party systems and are expected to lag behind niche parties which have a higher likelihood of acting as issue entrepreneurs. Niche parties therefore start the issue evolution sequence in multiparty systems, which is a crucial difference from the case of two-party systems. Empirical analyses of elite and mass polarization and issue salience have shown that this is indeed the case for the elite positioning and clarity part of the issue evolution sequence (Van de Wardt 2015; Arndt 2016).

We can further apply this logic to the electoral effects of issue evolution driven by niche parties in multiparty systems. If niche party positioning accounts for clarity on the new dimension, then it should also account for affect and mass alignment which means that a realignment has occurred after the electorate has become aware of and reacted to the increasing elite polarization induced by niche parties. Since "the new issue emerges as the leading possibility for making the voting decision" (Stimson 2004: 67), we should expect voters to react to those actors who have introduced and keep to emphasize the new issue dimension in a multiparty system. Consequently, niche party polarization should be a stronger predictor of mass realignment than mainstream party polarization in the first step.

I therefore expect that: 
H1: Only niche party polarization but not mainstream party polarization on the new dimension of conflict has significant effects on vote choice.

Following the qualification that elite polarization does not always automatically lead to issue evolution and realignment, (Carmines 1991; Carmines and Stimson 1989: 161; Carmines \& Woods 2002; Lindaman and Haider-Markel 2002: 105-106), we also need to account for issue salience as moderator. Carmines and Stimson 1989: 161) argued that the issue needs strong emotional response among the mass after elite polarization has become clear ('clarity'). In other words, when parties adopt more diverging positions, the salience of the issue increases among both the elite and the mass, and voters eventually evaluate parties more along those lines ('affect'). The changing issue agenda means that voters base their decisions less on the traditional dimension of conflict - even if they might keep the respective issue preferences - and now increasingly employ their preferences on the new dimension in assessing parties, which then "alters the fundamental link between citizen and party" (Carmines 1991: 74).

Accordingly, issue evolution only occurs if the new dimension of conflict has enough salience to condition the effects of the voters' attitudes on their vote choice, which means that niche party polarization is necessary but not sufficient. This means that salience of the new dimension of conflict moderates the electoral impact of the voters' attitudes on the new dimension of conflict implying an interactive relationship (Bélanger and Meguid 2008; Druckman et al. 2013; Levendusky 2010). Since political parties usually act as opinion leader in this sequence, I assume that changes in elite salience antecede changes in mass salience (Stimson 2004; see Arndt 2016 for a respective test with Danish data) and will therefore rely on elite salience as moderator variable below. Since the new dimension of vote choice is introduced by niche parties in multiparty systems, I formulate the following two conditional hypotheses:

$\mathrm{H} 2$ : Issue attitudes on the new dimension of conflict among the voters have a stronger effect on party choice the more salient the new dimension has become on the elite level. 
H3: Issue attitudes on the new dimension of conflict matter more for the choice of niche parties than for the choice of mainstream parties.

Finally, to substantiate that issue evolution has contributed to electoral change in the Danish multiparty system, I inspect whether partisan realignment is a function of elite polarization on a new dimension of conflict. For an issue evolution-driven partisan realignment, we need to observe that polarization conditions the effects of issue preferences, i.e. stronger effects of issue preferences on the new dimension the more parties polarize. In other words, voters should increasingly realign their party choice in line with their issue positions the more polarized this dimension has become. Thus, partisan sorting in the sense of Carmines and Stimson (1989: esp. 167) and Carsey and Layman (2006) should be contingent on niche party polarization in the Danish multiparty system.

H4: The realignment of voters from the left to the right on the new dimension of conflict follows an issue evolution process induced by niche parties. 


\section{Case selection and background}

Denmark is an ideal test case for applying Carmines and Stimson's concept of issue evolution to the analysis of partisan realignments in a multiparty system. Denmark has consistently had parliaments with at least five parties represented since the introduction of unicameralism in 1953. The Social Democrats had been dominant until 1973, forming all but one government between 1953 and 1973 . Afterwards, the center-right bloc formed more than half of all governments, which signals a change in the balance of power akin to the post-1964 U.S. party system. The Social Democrats' main opponent for most of the postwar period was the Liberal Party Venstre, a center-right party that traditionally adhered to market liberalism. In the 1990s, the Liberals adopted a more conservative platform on cultural issues and replaced the Social Democrats as the largest party from 2001 to 2011 (Mortensen 2008). These two parties are treated as mainstream parties in the analysis as they have competed for the Prime Ministership for most of the period since $1920 .^{1}$

As for niche parties, the Socialist People's Party ( $S F$, hereafter) made its breakthrough in the 1960s. It was originally an economically leftist workers' party, but eventually adopted a liberal platform on the environment, immigration, law enforcement, women's rights and other cultural issues. It did not join governments until 2011 but has been consistently represented in parliament since 1960, and always supported governments formed by the Social Democrats. This party is used as the main case for a leftist and culturally liberal niche party below because other, smaller radical left or liberal parties were either not permanently represented, split from or merged with other parties, or, in the case of the Social Liberal party (Radikale Venstre), occasionally cooperated with the center-right Liberals and Conservatives. The Social Liberals are used as a supplementary case (results reported in the Online Appendix, Figures A5-A7) since its political positioning on the new dimension examined here often matches that of the SF (see Arndt 2016).

In 1973, Danish politics was shocked by the so-called earthquake elections, with the number of parties doubling to ten and the emergence of new, mostly, niche parties. For the purpose of this 
paper, the Progress Party (Fremskridtsparti) is the most important new party on the right. In the 1970s, it espoused a right-wing libertarian anti-state and anti-government intervention platform. However, an immigration law passed in 1983 was regarded at the time as one of the world's most liberal, and Denmark quickly saw rising immigration from non-Western countries (Goul Andersen 2004; Hansen 2016). This marks a critical moment in Danish political history. The Progress Party and later its successor, the Danish People's Party (Dansk Folkeparti, together referred to in tables below as the New Right), focused increasingly on restrictive stances on immigration and tough lawand-order policies as a response to this sea change in Danish immigration policy, and after the party's anti-government intervention policies lost ground among Danish voters (Brøcker 1990). The party elite, led by its founder Mogens Glistrup and then-chairman Pia Kjærsgaard, realized the electoral potential of the immigration issue and started to realign the Progress Party's electoral platform and strategy (Kjærsgaard 2013: 60-65; Nielsen 2013: 185). This was eventually rewarded, and the Progress Party had halted its electoral decline by the late 1980s. Its successor, the Danish People's Party, has established itself as Denmark's third-largest party since 2000. Consequently, this party should be an important driver in the process of issue evolution in Denmark, and its distance from the SF on cultural issues captures elite polarization on a new dimension of conflict (see Arndt 2016).

To show that the Danish political elite increasingly competed on cultural issues after 1973, I used Danish Policy Agenda Project data on the Danish parliamentary agenda for the legislative periods from 1968 to 2011 (Green-Pedersen 2006, 2007, 2011). Following the method of various U.S.-based studies that use roll call data from Congress to assess the salience of issues among party elites (e.g., Carmines and Stimson 1989: 169ff; Lindaman and Haider-Markel 2002), I recoded 236 sub-issues into three categories: economic issues, cultural issues, and all other issues (see Online Appendix for coding). To gauge the prevailing issue agenda, I subtracted the share of cultural issues from the share of economic issues for all parliamentary activities in each electoral period examined. 
Positive values indicate that economic issues such as government intervention or unemployment were more salient among Danish political elites, while negative values indicate that cultural issues such as crime or immigration were more salient. As the Danish parliamentary system is unicameral and no strong regional parliaments exist, it is reasonable to assume that this procedure captures the elite agenda quite well.

Figure 1 reveals that the elite agenda in Denmark has shifted considerably. Until the electoral term 1981-1984, economic issues were always more salient than cultural issues, as illustrated by the exclusively positive values. Beginning with the electoral term 1981-1984, however, in which the immigration law was passed, the salience of economic issues crumbles and cultural issues become more salient, becoming the dominant dimension of political competition. This development can also be seen when using the voters' agenda (see Figure A1 in online appendix).

[Figure 1 about here]

Having demonstrated the changing elite agenda in Figure 1 and thus elite salience in Denmark after 1968, the next step is to demonstrate elite (de-)polarization on the two dimensions. I used the Comparative Manifesto Project and calculated the positions of the two mainstream parties (Social Democrats and Liberals) and the three niche parties that were consistently represented in the Danish parliament from 1973 (Progress Party/Danish People's Party, Socialist People's Party and Social Liberals) on economic and cultural issues. I followed Bakker and Hobolt's (2013) coding of the Comparative Manifesto Project data for polarization in two-dimensional party systems (Volkens et al. 2013). ${ }^{2}$ The economic dimension distinguishes pro-state and pro-government intervention from free-market and anti-government intervention positions, where higher values indicate the latter. The cultural dimension distinguishes cultural liberalism from cultural conservatism, again with higher 
values indicating a more right-wing or conservative position (see Online Appendix for detailed coding). The results appear in Figure 2 and 3.

[Figure 2 about here]

Figure 2 depicts the five parties' positions on economic issues since the electoral term 19681971. Until 1984, party polarization on economics was strong, with the Progress Party as the advocate of free market economics and the Socialist People's Party as its antipode. The two mainstream parties represented moderate pro-market (Liberals) and moderate pro-state (Social Democrats) platforms, with the Social Liberals falling in between for most years. Elite polarization on the economy then diminished after the electoral term 1981-1984 as the parties began to converge on the state-market dimension. After the turn of the millennium, four out of five parties took centrist to moderately pro-state intervention positions, and the ideological distances between the two most extreme niche parties (the Progress Party/Danish People's Party and the Socialist People's Party) declined from more than 80 points (late '70s) to around 30 points by 2000 .

[Figure 3 about here]

Figure 3 reveals an opposite pattern of elite polarization on cultural issues. Until 1984, there was no substantial polarization on cultural issues between the five parties under review. Only the SF adopted a culturally liberal platform from the beginning, while all other parties had moderate positions close to zero (with the exception of the Liberals in 1979). The Progress Party also did not have a clear standpoint on the cultural dimension in the early years. This picture changed with the electoral term 1981-1984 and the immigration law. Afterwards, especially the Progress Party (and later Danish People's Party), began to take clear positions. Taken as a whole, we can see growing 
ideological distances, with the New Right increasingly taking culturally conservative positions and the Socialist People's Party and the Social Liberals taking culturally liberal positions. The mainstream parties polarized less on cultural issues, although there is a tendency for the Liberals and Social Democrats to take more distinct positions on cultural issues after 1984 than before. ${ }^{3}$

These illustrations of elite salience and elite polarization clearly show that Danish politics has become two-dimensional since 1973 and that polarization around cultural issues has replaced polarization around economics as the major cleavage. Niche parties polarized more strongly on the new dimension of conflict, which confirms the expectation that issue evolution is driven by niche parties rather than mainstream parties. ${ }^{4}$ The next step is to investigate whether this elite polarization had effects on general Danish voting behavior and to test the respective hypotheses on the role of niche parties in realignment. First, I briefly introduce the data and measures used. 


\section{Data}

To examine how elite polarization in Denmark has affected vote choice, and to inspect whether realignment was the final product of issue evolution in Denmark, I pooled the Danish National Election Studies 1971-2011 (DNES) and merged them with the CMP data and the Danish Policy Agenda Project to capture elite salience and polarization over time. ${ }^{5}$ The dependent variable to test the first two hypotheses is vote choice, where I used four party contrasts: 1) Social Democrats vs. Liberals, 2) Social Democrats vs. New Right, 3) Liberals vs. SF, and 4) SF vs. New Right. If my hypotheses are right, then the we should observe the strongest effects for the niche party contrast SF vs. New Right and the weakest for the mainstream contrast Social Democrats vs. Liberals. For the fourth hypothesis, I constructed two measures on voter migration based on the vote choice in the current election and the vote choice at the last parliamentary election (based on the vote recall question). These measures are explained in detail below. One main reason to use actual vote choice to capture partisanship is that the DNES do not contain a party identification variable in all years as common in American studies. The main independent variables in the analysis are elite polarization and elite salience of economic issues and cultural issues. To construct measures for mainstream versus niche party polarization, I took the parties' positions on the two dimensions as depicted in Figures 2 and 3. I then subtracted the Social Democrats' from the Liberals' positions to obtain mainstream party polarization and subtracted the Socialist People's Party's positions from the New Right's positions on both dimensions to obtain niche party polarization. The use of these contrasts to capture polarization in a multiparty system has been validated by Arndt (2016) and mirrors the 'Sartori measure' that captures polarization between the most viable left and right party on a given issue dimension (e.g., Crepaz 1990). For elite issue salience, I used the share of economic and cultural issues of all parliamentary activities for each election term before the respective elections to capture that elite salience antecedes mass reaction. 
To test my hypotheses that issue attitudes on the new dimension of conflict have a stronger effect on party choice the more polarized and the more salient the new dimension has become, I used six items measuring attitudes towards economic inequality, the free market, taxes, immigration, law enforcement and the environment that were repeatedly asked in Danish National Election Studies. Three of them tap into attitudes towards economic issues:

Politics should achieve the same economic conditions for everybody irrespective of education and occupation. (1 agree completely, 2 agree partly, 3 neither/nor, 4 disagree partly, 5 disagree completely)

A says: Private businesses and industry should, to a larger degree, have the right to make decisions regarding their own businesses.

B says: The state should control private businesses. Under no circumstances should public control be less than it is in the Denmark of today. (1 agree with A, 2 agree with $\mathrm{B}, 3$ neither A nor B)

Higher incomes ought to be taxed more than is the case today. (1 agree completely, 2 agree partly, 3 neither/nor, 4 disagree partly, 5 disagree completely)

The other three tap into respondents' attitudes towards cultural issues and have a common introduction:

We'd like to hear your views on some important political issues. Could you tell me whether you agree or disagree with each of the following proposals? How strongly do you feel? 
Immigration constitutes a serious threat to our national culture. (1 agree completely, 2 agree partly, 3 neither/nor, 4 disagree partly, 5 disagree completely)

Violent felony should be punished more strongly than is the case today. (1 agree completely, 2 agree partly, 3 neither/nor, 4 disagree partly, 5 disagree completely)

Economic growth must be maintained by further development of industry even if this comes at the expense of environmental interests. (1 agree completely, 2 agree partly, 3 neither/nor, 4 disagree partly, 5 disagree completely)

All items have been consistently included in Danish Election Studies since the mid-1980s and were recoded into two five-point scales ranging from 1 "agree with all pro-government intervention/culturally liberal positions" to 5 "agree with all free market/culturally conservative positions" to measure economic liberalism $(\mathrm{M}=2.84, \mathrm{SD}=1.10)$ and cultural conservatism $(\mathrm{M}=3.26$, $\mathrm{SD}=1.07)$. The earlier election studies only contained two of these items. In this case, the calculation of the scales was adapted. In other cases, it was possible to use similar items to capture the respective attitudes (see the Online Appendix for details). This is mainly the case for attitudes towards immigration/immigrants, where the early surveys included items on attitudes towards guest workers and not immigration as a cultural threat.

The scales for issue attitudes were then interacted with elite salience (Hypotheses 2 and 3) and mainstream and niche party polarization (Hypothesis 1 and Hypothesis 4 ) to inspect whether the effect of cultural liberalism/conservatism increases with the rising importance of cultural issues among Danish political elites. The models also include controls for age, social class, education, sex and union membership. 


\section{Analysis}

The impact of issue attitudes on vote choice across elite salience

As a first step, I inspect Carmines and Stimson's argument on issue-based realignments; that is, whether the new dimension of conflict provoked enough emotional response to change party affiliations in Denmark. To reiterate, I expect that "Issue attitudes on the new dimension of conflict among the voters have a stronger effect on party choice the more salient the cultural dimension has become on the elite level" (Hypothesis 2) and "Issue attitudes on the new dimension of conflict matter more for the choice of niche parties than for the choice of mainstream parties" (Hypothesis 3). I test these hypotheses by interacting the mass issue scales on economic liberalism and cultural conservatism with elite issue salience of the economy and culture. Table 1 presents the conditional effects of issue attitudes across the level of elite issue salience on vote choice for the four selected party contrasts using multilevel logit models with election years as macro-level to capture the clustering of individuals within election studies. ${ }^{6}$ The party contrasts represent one mainstream party contrast first (Social Democrats vs. Liberals), two mainstream against niche contrasts (Social Democrats vs. New Right; Liberals vs. SF), and finally a niche party contrast (SF vs. New Right).

[Table 1 about here]

The interaction elite salience culture ${ }^{*}$ cultural conservatism is significant for all four party contrasts and always in favor of the two right-wing parties vis-à-vis their left competitors. The Liberals and the New Right attracted more culturally conservative voters the more Danish politics was about cultural issues. This supports Hypothesis 2 postulating that increased elite salience of cultural issues strengthens the effect of cultural conservatism on vote choice in Denmark. The difference between the interaction for the niche party contrast New Right vs. SF (0.139) and the respective mainstream party contrast Liberals vs. Social Democrats (0.079) is also significant at $\mathrm{p}<.05$ which corroborates 
Hypotheses 3 that cultural conservatism matters more for the choice of niche parties than for the choice of mainstream parties. This is further supported by looking at the other measures for elite salience and elite polarization in Table 1. Most of the significant elite salience and elite polarization measures occur for the contrast New Right vs. SF in the right-hand column, while there are only two significant elite effects for the contrast Social Democrats vs. Liberals in the left-hand column.

To give an illustration of the effect sizes, I visualize the marginal effects of the interaction terms from the models in Table 1 given the not-always-straightforward interpretation of coefficients and p-values in logit models containing interactions (Brambor et al. 2006). I report both the effects for economic liberalism and cultural conservatism to allow a comparison of the effect strengths of the traditional and new dimension of partisan conflict in Denmark.

[Figure 4 about here]

Figure 4 shows that the effects of economic liberalism and cultural conservatism on vote choice increase with the salience of the respective issue dimension. Moreover, cultural conservatism has a stronger effect if cultural issues dominate the parliamentary agenda compared to the same effect for economic issues (the interaction term with culture is significantly stronger than the interaction term with economy at $\mathrm{p}<.05$ for all four party contrasts, see Table 1 and Tables A2A5). ${ }^{7}$ Again, the effect of being culturally conservative increases with the salience of cultural issues, and the effects consistently boost support for the two right-wing parties vis-à-vis their left opponents.

Particularly, the impact of being culturally conservative increases somewhat stronger for the contrasts involving the New Right compared to the contrasts involving the Liberals, even though the differences in effect strengths are not very strong. The marginal effect of cultural conservatism on the probability of supporting the New Right vis-à-vis the Social Democrats is around 2-3 
percentage points when the salience of cultural issues was at its minimum. This marginal effect of cultural conservatism on voting for the New Right vis-à-vis the Social Democrats increases to around 26 percentage points when cultural issues reach their empirical maximum (party contrasts on the upper right-hand side). The respective marginal effect on voting for the Liberals is 20 percentage points in comparison with the Social Democrats and around 12 percentage points in comparison with the Socialist People's Party (party contrasts on the left-hand side) - again with the salience of culture at its maximum.

Together with the coefficients from Table 1, these marginal effects confirm Hypothesis 2 because the significantly increasing electoral effects of conservative attitudes on culture result from the intensified party competition around cultural issues. ${ }^{8}$ Furthermore, the results confirm Hypothesis 3 since the marginal effects were stronger for party contrasts involving niche parties and strongest for the contrast New Right vs. SF. Danish partisans increasingly based their vote choice on cultural attitudes the more salient these issues became in Danish politics, signalling new policy alignments (Carmines and Stimson 1989: 161).

\section{The impact of issue attitudes on vote choice across polarization}

Having shown that the impact of policy issues on vote choice increases with their salience, the second step is to illustrate how the increasing polarization of cultural issues contributes to the understanding of vote choice and realignments within the Danish electorate since 1971 (Hypothesis 1 and Hypothesis 4). To do this, I used the vote choice and the vote recall question from the last parliamentary election to create two measures of partisan realignment (and sorting). The first captures the realignment of voters with the New Right (Danish People's Party/Progress Party) - the driving force and main winner of the issue evolution process in Denmark. This variable has three categories 0 "Did not realign with New Right, voted other party in both elections" 1 "Stayed with New Right, voted for them in both elections" 2 "Realigned with New Right, has voted other party in 
election before". The rationale is to inspect whether elite polarization on culture makes voters with culturally conservative attitudes more likely to (re-)align with the New Right. Moreover, it allows inspecting whether there is a sorting procedure as voters with culturally conservative positions should have an increasing propensity to keep voting the New Right as elites get more polarized on this dimension. As second measure, I captured voter migration from the left-wing to the right-wing bloc between two elections. ${ }^{9}$ This variable has four categories 0 "stayed within left bloc" 1 "stayed within right bloc" 2 "realigned with left" 3 "realigned with right", where only the latter two are presented in the analysis that follows. To reiterate, the right-wing parties had broken the structural majority of the social democrats and the other leftist parties after the 1973 Earthquake Election. If this is the consequence of an issue evolution process, then we should observe an increasing effect of cultural conservatism on the likelihood of realigning with the right bloc the stronger the niche parties polarize on culture.

The models have a similar setup as the models above and include interactions elite polarization on culture ${ }^{*}$ cultural conservatism (the five point scale described above). ${ }^{10}$ The interactions first test whether the effect of niche party polarization is systematically stronger than the effect of mainstream party polarization (Hypothesis 1). Second, they test whether the impact of attitudes on voting behaviour changes in response to the polarisation of parties and thus the resulting clarity of issues (see Carmines and Woods 2002 for a similar setup). If Hypothesis 4 is true, then we should see increasing marginal effects of cultural conservatism on realigning and sticking with the New Right and the right-wing bloc, the more niche parties polarize on culture. I again present the marginal effects of cultural conservatism across the observed polarization of mainstream and niche parties in the period under review (the coefficients appear in the Online Appendix, Tables A6-A7).

[Figure 5 about here] 
Figure 5 presents the marginal effect of cultural conservatism on staying with other parties, realigning with the New Right and staying with the New Right across the observed polarization on culture for mainstream and niche parties. The left-hand panel reveals that mainstream party polarization on culture does only very mildly increase the effect of cultural conservatism on New Right alignment. The effect of being culturally conservative on shifting to or staying with the New Right is always positive, but does not strongly increase as mainstream parties do take more distant positions on culture.

This differs when we look on the right-hand side, where we can clearly observe an increasing effect of cultural conservatism on realigning and staying with the New Right as niche parties take more distinct positions cultural issues. The likelihood that a culturally conservative voter keeps voting the New Right is only increased by one to two percent if niche party polarization on culture is low, but increases to eight percent if niche party polarization is at its maximum. This means that conservative voters stay with the New Right if party competition is centered around on culture - an indirect proof of a sorting procedure among Danish voters. Moreover, the chance of switching to the New Right when moving one unit on the cultural conservatism scale is below one percent when niche party polarization is below zero, but increases to more than three percent if niche parties have fully polarized on the new dimension (56 points distance in Figure 5). This difference is also significant at $\mathrm{p}<.05$. Hence, niche party polarization conditioned the effect of cultural conservatism on realignment as voters with conservative attitudes sorted themselves into the New Right the stronger niche parties polarized the new dimension of conflict.

An even clearer pattern occurs when looking at the voter migration between the left-wing and right-wing bloc of parties.

[Figure 6 about here] 
Again, mainstream party polarization on the new dimension does not increase the effect of cultural conservatism on shifting from the left to the right bloc (and vice versa). The effect of cultural conservatism on defecting from a left to a right party is not surprisingly always positive, but does not increase as mainstream parties distance themselves on cultural issues (left-hand side of Figure 6). This is different on the right-hand of Figure 6, where the effect of cultural conservatism on rightwing realignment increases the stronger niche parties polarize the cultural dimension. The effect of cultural conservatism on right-wing realignment is even negative as long as niche party polarization has negative values meaning that the SF was more conservative than the Progress Party (as the SF was against wage competition with immigration in its early days). This changes as the Progress Party and later Danish People's Party took more conservative positions. The effect of cultural conservatism on realigning with the right-wing bloc gets significantly stronger the stronger the niche parties polarize. A fully polarized cultural dimension increases the effect of conservatism on defecting to the right-wing bloc by around 1.5 percent. Another notable finding is that there is no significant negative effect of cultural conservatism on realigning with the left-wing bloc since the confidence intervals always include zero. Accordingly, cultural liberalism has not increased the likelihood of shifting to the left, because the respective marginal effect is never significant. Second, it means that niche party polarization on culture has been one driving force for bereaving the left of its structural majority from the pre-1973 party system as postulated in Hypothesis 4. Niche party polarization on culture has moved culturally conservative voters from the left to the right bloc, whereas the left could not equally compensate this by pulling culturally liberal voters from the right bloc. The results from the analysis on voter migration therefore demonstrate how issue evolution induced by niche parties has contributed to the decline of the left in Denmark and the strengthening of the right in the post-1973 party system. 


\section{Summary and Conclusion}

This paper analyzed the realignment processes around new cultural issues in the Danish multiparty system in 1971-2011. While previous analyses of issue evolution and realignments had been limited to two party-systems, this paper applied Carmines and Stimson's theory on party system transformation and electoral change to a multiparty system. I argued that electoral change under multiparty competition is not driven by mainstream parties, as is in a two-party system, but by niche (and mainly new) parties who face a different incentive structure than mainstream parties in competing on and polarizing a new issue dimension.

The results demonstrated that Carmines and Stimson's $(1986,1989)$ model of issue evolution travels to a multidimensional multiparty system, when it is refined to describe the role of niche party competitors. Realignment in the Danish electorate was a consequence of increasing niche party polarization on cultural issues (and accompanied by depolarization on economic issues). Furthermore, niche party polarization has also driven the salience of the new issue dimension, to which partisans then reacted by aligning their preferences (see Arndt 2016). In line with Carmines and Stimson's model, my models demonstrated that elite polarization on cultural issues strengthened the impact of cultural issues on vote choice, because culturally conservative voters increasingly aligned with the right-wing parties.

This had also consequences for the balance of power in the Danish party system. Similar to the rise of the GOP at the expense of the Democratic party in the U.S. in the post-1964 party system, the emergence of a new dimension of conflict changed the balance of power in Denmark and bereaved the Social Democrats their dominant position. While the Danish Social Democrats could govern from 1953 to 1982 with only two short-term center-right governments in between (1968-71 and 1973-75), the majority of governments in Denmark in the post-1973 party system was formed by the center-right. On that score, four out of the last five governments in Denmark have been right-wing governments formed by the Liberals, who could capitalize on the realignment 
induced by the New Right after the 1983 immigration law and the Liberals' own adoption of culturally conservative positions in the late 1990s. Consequently, niche party polarization accounts for issue-based realignments in Denmark after 1973, as the strong emotional reactions around issues like immigration or crime fundamentally reshaped the electoral landscape.

Thus, one important implication of this analysis is that the emergence of cultural conflicts, as demonstrated by Kriesi et al. (2008), is not only a bottom-up process, where elites react to attitudes among the mass public. Rather, strategic considerations by niche party elites to compete on new issue dimensions have contributed to the restructuring of the electoral landscape in many Western countries with multiparty systems. Here, mainstream parties have trailed behind their niche party competitors in adapting their positions to the new issue dimension. While this paper adopted Carmines and Stimson's model to the issue evolution processes under multiparty competition, there are various obvious issues for future research on issue evolution under multiparty competition to examine in order to substantiate my findings.

First, Layman and Carsey (2002) have asked how much of the issue evolution process in the United States can be attributed to conflict extension; that is, a reinforcement of already existing partisan cleavages by new issues that increase the leverage of pre-existing issue divides on voting. Conflict extension might be weaker in a multiparty system since a new issue dimension of conflict can be more independent of the traditional dimension of conflict when the choice set is not limited to two parties and mainstream parties still mobilize a considerable number of voters through their positions on the "old" dimension of competition. On the other hand, it might well be that issues such as welfare benefits get increasingly connected to immigration as in the U.S. This is a topic to be examined by future research, preferably using panel data containing items on political awareness, knowledge and party identification, which was not possible in the present analysis due to data limitations. 
A second issue for future research is the role of elite cues in the issue evolution process in multiparty systems. One obvious limitation of the present study is the focus on elite polarization and voting behavior, while the effects of elite cues on the new dimension of conflict and party identification were left out. The relationship between partisanship, elite cues and opinion formation might be less straightforward in a multiparty setup, where niche party competitors do not have a strong supporter base with strong levels of party identification at the beginning of the issue evolution and sorting process. Rather, partisanship might be built up consecutively after niche party elites have sent cues to the electorate, and after the respective issue attitudes have turned into votes for niche party competitors. This can inspected by panel analysis tapping into the effects of niche party cues vis-à-vis mainstream party cues on party identification.

Third, future research might identify the conditions under which niche parties' and issue entrepreneurs' cues fail to evoke an issue evolution. Lindaman and Haider-Markel (2002) have analyzed culture war issues that failed to produce a response at the mass level in the United States. There might be similar issues under multiparty competition where new parties fail to produce a lasting response among the broader public even though the entry of new issues and issue entrepreneurs is principally easier here. One current example is the different success of the Pirate Party and the AfD in Germany. Both new parties started with some spectacular success at state elections in 2011-2014. However, only the AfD has had lasting success with a conservative platform around immigration, crime, and culture, while the Pirate Party could not mobilize voters persistingly with its vaguer platform around digital democracy, transparency, privacy, and copyrights. This likely relates to the distinction between easy issues that have the potential for an issue evolution and those 'hard' issues that fail to provoke enough salience (Carmines \& Stimson 1989: 11-12). Accordingly, further applications of the issue evolution perspective could tap into macro- and micro-level factors that distinguish successful issue evolution from unsuccessful attempts. 


\section{Notes}

${ }^{1}$ The Conservative Party was larger than the Liberals during the 1980s, but as these two center-right parties usually form coalitions together I have excluded the Conservatives given the limited value added.

${ }^{2}$ This measure has been validated by Bakker and Hobolt (2013: 34ff) since the parties' positions on the two dimensions correspond very closely to expert judgements from the Chapel Hill Expert Survey as well as party placements from Eurobarometer surveys.

${ }^{3}$ The picture is even clearer when using the parties' positions on immigration (see Figure A2 in the Online Appendix).

${ }^{4}$ Analyses of the perceived party positions on the economy and culture shows that partisans were aware of the strong polarization of niche parties on culture and the convergence of most parties on economic issues by the late 1990s and early 2000s (Arndt 2016)

${ }^{5}$ Data is available at the Danish Data Archive (https://www.sa.dk/en/services/danish-data-archive). I excluded the 1988 election given it was a snap election to consolidate a right-wing coalition government and the rather limited data for elite salience in the very short term 1987-88. Accordingly, I treated the years 1987-1990 as one election period for the elite-level data.

${ }^{6}$ All models have be rerun in GLLAMM as multinomial specifications that also included the Social Liberals, the Conservatives, and the various center parties. The results yield very similar conclusions and are available on request.

${ }^{7}$ The results are similar if using a measure of salience at the individual level instead of elite salience; see the robustness check in Figure A3 in the Online Appendix.

${ }^{8}$ Replacing the scales on attitudes with single items on taxes/redistribution and immigration yields similar findings (see Figure A4 in the Online Appendix). The same goes when replacing elite salience on the two dimensions with the parties' positions on culture and economy (robustness check available on request)

${ }^{9}$ The left-wing bloc contains the Social Democrats, the SF, the Social Liberals, the various radical left parties, while the right-wing bloc contains the Liberals, the Danish People's Party/Progress Party, the Conservatives, and the various center parties. I adjusted for bloc affiliation in those years, where center parties cooperated with the left parties and not the right.

${ }^{10}$ The marginal effects shown here are based on multinomial logit models with robust standard errors. The results for the realignment models are very similar to multilevel multinomial logit models ran in GLLAMM (available on request).

\section{Supplementary material and replication data for this article is available with the manuscript on the PRQ} website. 
References

Adams, Greg D. 1997. “Abortion: Evidence of an Issue Evolution.” American Journal of Political Science 38: 718-737.

Arndt, Christoph. 2016. "Issue Evolution and the Remaking of Partisan Alignments in a European Multiparty System: Elite and Mass Repositioning in Denmark 1968-2011.” European Union Politics 17: 660-682.

Bakker, Ryan, and Sara B. Hobolt. 2013. "Measuring Party Positions: Political Choice Matters.” In Political Choice Matters: Explaining the Strength of Class and Religious Cleavages in Crossnational Perspective, edited by G. Evans and N. D. De Graaf, 27-45. Oxford: Oxford University Press.

Bélanger, Éric, and Bonnie M. Meguid. 2008. “Issue Salience, Issue Ownership, and Issue-based Vote Choice." Electoral Studies 27: 477-491.

Bischof, Daniel. 2015. "Towards a Renewal of the Niche Party Concept: Parties, Market Shares and Condensed Offers.” Party Politics, OnlineFirst, doi: 10.1177/1354068815588259.

Brambor, Thomas, William. R. Clark, and Matt Golder. 2006. "Understanding Interaction Models: Improving Empirical Analyses." Political Analysis 14: 63-82.

Brøcker, Anne. 1990. ”Udlændingelovgivning i Danmark, 1983-1986: Faktorer i den Politiske Beslutningsproces.” Politica 22: 332-345.

Carmines, Edward G. 1991. "The Logic of Party Alignments.” Journal of Theoretical Politics 3: 65-80.

Carmines, Edward G., and James A. Stimson. 1986. "On the Structure and Sequence of Issue Evolution." American Political Science Review 80: 902-921.

Carmines, Edward G., and James A. Stimson. 1989. Race and the Transformation of American Politics. Princeton: Princeton University Press.

Carmines, Edward G., and James Woods. 2002. "The Role of Party Activists in the Evolution of the Abortion Issue." Political Behavior 24: 361-377.

Carsey, Thomas M., and Geoffrey C. Layman. 2006. "Changing Sides or Changing Minds? Party Identification and Policy Preferences in the American Electorate." American Journal of Political Science 50: 464-477.

Crepaz, Markus. 1990. "The Impact of Party Polarization and Postmaterialism on Voter Turnout. A Comparative Study of 16 Industrial Democracies.” European Journal of Political Research 18: 183-205. 
DNES. 2016. The Danish National Election Study. Department of Political Science, Aarhus University.

De Vries, Catherine E., and Sara B. Hobolt. 2012. "When Dimensions Collide: The Electoral Success of Issue Entrepreneurs.” European Union Politics 13: 246-268.

Druckman, James N., Erik Peterson, and Rune Slothuus. 2013. "How Elite Polarization Affects

Public Opinion Formation.” American Political Science Review 107: 57-79.

Goul Andersen, Jørgen. 2004. “Dansk Folkeparti och Nya Konfliktdimensioner i Dansk Politik.” In

Från Le Pen till Pim Fortuyn: Populism och parlamentarisk högerextremism i dagens

Europa, edited by Jens Rydgren and Anders Widfeldt, 147-170. Malmö: Liber.

Green-Pedersen, Christoffer. 2006. "Long-term Changes in Danish Party Politics: The Rise and Importance of Issue Competition.” Scandinavian Political Studies 29: 219-235.

Green-Pedersen, Christoffer. 2007. "The Growing Importance of Issue Competition: The Changing Nature of Party Competition in Western Europe.” Political Studies 55: 608-628.

Green-Pedersen, Christoffer. 2011. Partier i Nye Tider: Den Politiske Dagsorden i Danmark. Aarhus: Aarhus University Press.

Hansen, Sara M. 2016. Udlaendingelove 1983-2002. Danmarkshistorien. Aarhus University. Hobolt, Sara B., and Catherine E. de Vries. 2015. "Issue Entrepreneurship and Multiparty Competition." Comparative Political Studies 48: 1159-1185.

Kjærsgaard, Pia. 2015. Fordi Jeg Var Nфdt til Det. Copenhagen: Gyldendal.

Kriesi, Hanspeter, Edgar Grande, Roman Lachat, et al. 2008. Western European Politics in the Age of Globalization. Cambridge: Cambridge University Press.

Layman, Geoffrey C. 2001. The Great Divide: Religious and Cultural Conflict in American Party Politics. New York: Columbia University Press.

Layman, Geoffrey C., and Thomas M. Carsey. 2002. "Party Polarization and 'Conflict Extension' in the American Electorate.” American Journal of Political Science 46: 786-802.

Levendusky, Matthew S. 2010. “Clearer Cues, More Consistent Voters: A Benefit of Elite Polarization.” Political Behavior 32: 111-131.

Lindaman, Kara, and Donald Haider-Markel. 2002. "Issue Evolution, Political Parties, and the Cultural Wars.” Political Research Quarterly 55: 91-110.

Meyer, Thomas. M., and Markus Wagner. 2013. "Mainstream or Niche? Vote-seeking Incentives and the Programmatic Strategies of Political Parties." Comparative Political Studies 46: 12461272 .

Mortensen, Hans 2008. Tid til Forvandling: Venstres Vej til Magten. Copenhagen: Gyldendal. Nielsen, Flemming C. 2013. Glistrup: En Biografi om en Anarkist. Copenhagen: Gyldendal. 
Raymond, Christopher, and Brian M. B. Feltch. 2014. "Parties, Cleavages and Issue Evolution: The Case of the Religious-Secular Cleavage in Chile." Party Politics 20: 429-443.

Riker, William H. 1982. Liberalism Against Populism: A Confrontation between the Theory of Democracy and the Theory of Social Choice. San Francisco: Freeman.

Stimson, James A. 2004. Tides of Consent. Cambridge: Cambridge University Press.

Stimson, James A., Cyrille Thiébaut, and Vincent Tiberj. 2012. "The Evolution of Policy Attitudes in France." European Union Politics 13: 293-316.

Stevens, Daniel. 2013. "Issue Evolution in Britain: The Debate on European Union Integration, 1964-2010.” European Journal of Political Research 52: 536-557.

Stubager, Rune. 2010. “The Development of the Education Cleavage: Denmark as a Critical Case." West European Politics 33: 505-533.

Van de Wardt, Marc, Catherine. E. De Vries, and Sara B. Hobolt. 2014. "Exploiting the Cracks: Wedge Issues in Multiparty Competition.” The Journal of Politics 76: 986-999.

Van de Wardt, Marc. 2015. "Desperate Needs, Desperate Deeds: Why Mainstream Parties Respond to the Issues of Niche Parties." West European Politics 38: 93-122.

Volkens, Andrea, Pola Lehmann, Nicolas Merz, et al. 2013. The Manifesto Data Collection: Manifesto Project (MRG/CMP/MARPOR). Berlin: Wissenschaftszentrum Berlin für Sozialforschung (WZB). 
Table 1: Effects of economic liberalism, cultural conservatism, and elite issue salience on vote choice for four selected party contrasts

\begin{tabular}{|c|c|c|c|c|c|c|c|c|}
\hline \multirow[t]{2}{*}{ Party positions and political attitudes } & \multicolumn{2}{|c|}{$\begin{array}{l}\text { M1: Social Democrats } \\
\text { vs. Liberals }\end{array}$} & \multicolumn{2}{|c|}{$\begin{array}{l}\text { M2: Social Democrats } \\
\text { vs. New Right }\end{array}$} & \multicolumn{2}{|c|}{$\begin{array}{c}\text { M3: Liberals } \\
\text { vs. Socialist People's Party }\end{array}$} & \multicolumn{2}{|c|}{$\begin{array}{l}\text { M4: Socialist People's Party } \\
\text { vs. New Right }\end{array}$} \\
\hline & $\begin{array}{l}\text { Economic } \\
\text { liberalism }\end{array}$ & $\begin{array}{r}\text { Cultural } \\
\text { conservatism }\end{array}$ & $\begin{array}{l}\text { Economic } \\
\text { liberalism }\end{array}$ & $\begin{array}{r}\text { Cultural } \\
\text { conservatism }\end{array}$ & $\begin{array}{l}\text { Economic } \\
\text { liberalism }\end{array}$ & $\begin{array}{r}\text { Cultural } \\
\text { conservatism }\end{array}$ & $\begin{array}{l}\text { Economic } \\
\text { liberalism }\end{array}$ & $\begin{array}{r}\text { Cultural } \\
\text { conservatism }\end{array}$ \\
\hline \multirow{2}{*}{$\begin{array}{l}\text { Distance Liberals-Social Democrats } \\
\text { on economy }\end{array}$} & $0.019 *$ & 0.016 & -0.005 & -0.005 & $-0.044 * * *$ & $-0.039 * * *$ & $0.021 * *$ & $0.024 * * *$ \\
\hline & $(0.008)$ & $(0.008)$ & $(0.008)$ & $(0.008)$ & $(0.005)$ & $(0.010)$ & $(0.007)$ & $(0.007)$ \\
\hline \multirow{2}{*}{$\begin{array}{l}\text { Distance Liberals-Social Democrats } \\
\text { on culture }\end{array}$} & 0.003 & 0.011 & -0.004 & 0.001 & $-0.014 *$ & $-0.035^{*}$ & 0.012 & $0.021 *$ \\
\hline & $(0.011)$ & $(0.011)$ & $(0.011)$ & $(0.011)$ & $(0.007)$ & $(0.014)$ & $(0.009)$ & $(0.009)$ \\
\hline \multirow[t]{2}{*}{ Distance New Right-SF on economy } & -0.000 & 0.001 & 0.002 & 0.004 & $-0.027 * * *$ & $-0.028 *$ & $0.036 * * *$ & $0.040 * * *$ \\
\hline & $(0.009)$ & $(0.009)$ & $(0.009)$ & $(0.009)$ & $(0.006)$ & $(0.011)$ & $(0.008)$ & $(0.008)$ \\
\hline \multirow[t]{2}{*}{ Distance New Right-SF on culture } & -0.010 & -0.008 & 0.006 & 0.008 & -0.005 & -0.006 & $0.027 * * *$ & $0.031 * * *$ \\
\hline & $(0.009)$ & $(0.009)$ & $(0.008)$ & $(0.008)$ & $(0.004)$ & $(0.010)$ & $(0.006)$ & $(0.006)$ \\
\hline \multirow[t]{2}{*}{ Elite salience of economic issues } & 0.104 & 0.076 & -0.071 & 0.019 & $-0.169 * * *$ & -0.140 & -0.043 & $0.117 * *$ \\
\hline & $(0.076)$ & $(0.071)$ & $(0.075)$ & $(0.066)$ & $(0.050)$ & $(0.085)$ & $(0.064)$ & $(0.043)$ \\
\hline \multirow[t]{2}{*}{ Elite salience of cultural issues } & $0.216^{* *}$ & -0.079 & 0.120 & $-0.347 * * *$ & $-0.305 * * *$ & 0.023 & $0.237 * * *$ & $-0.232 * *$ \\
\hline & $(0.078)$ & $(0.085)$ & $(0.074)$ & $(0.088)$ & $(0.035)$ & $(0.105)$ & $(0.047)$ & $(0.080)$ \\
\hline \multirow[t]{2}{*}{ Economic liberalism scale } & $1.191 * * *$ & $1.187 * * *$ & $0.308 * *$ & $0.745 * * *$ & $-1.738 * * *$ & $-1.697 * * *$ & $0.482 * *$ & $1.084 * * *$ \\
\hline & $(0.095)$ & $(0.036)$ & $(0.117)$ & $(0.046)$ & $(0.146)$ & $(0.062)$ & $(0.183)$ & $(0.075)$ \\
\hline \multirow{2}{*}{$\begin{array}{l}\text { Salience of economic } \\
\text { issues*Economic liberalism scale }\end{array}$} & -0.001 & & $0.039 * * *$ & & 0.009 & & $0.057 * * *$ & \\
\hline & $(0.008)$ & & $(0.010)$ & & $(0.013)$ & & $(0.016)$ & \\
\hline \multirow[t]{2}{*}{ Cultural conservatism scale } & $0.856 * * *$ & $-0.507 * * *$ & $1.395 * * *$ & $-0.664 * *$ & $-1.454 * * *$ & 0.394 & $1.906^{* * *}$ & -0.473 \\
\hline & $(0.036)$ & $(0.153)$ & $(0.055)$ & $(0.215)$ & $(0.058)$ & $(0.249)$ & $(0.083)$ & $(0.303)$ \\
\hline \multirow{2}{*}{$\begin{array}{l}\text { Salience of cultural issues*Cultural } \\
\text { conservatism scale }\end{array}$} & & $0.079 * * *$ & & $0.118 * * *$ & & $-0.106 * * *$ & & $0.139 * * *$ \\
\hline & & $(0.009)$ & & $(0.012)$ & & $(0.014)$ & & $(0.018)$ \\
\hline \multirow[t]{2}{*}{ Constant } & $-11.596 * * *$ & $-6.356 * *$ & $-8.840 * * *$ & -1.892 & $18.461 * * *$ & $12.808 * * *$ & $-15.746 * * *$ & $-10.002 * * *$ \\
\hline & $(2.347)$ & $(2.402)$ & $(2.233)$ & $(2.310)$ & (1.183) & $(2.917)$ & $(1.548)$ & $(1.767)$ \\
\hline $\mathrm{N}$ & 7,694 & 7,694 & 5,408 & 5,408 & 5,103 & 5,103 & 2,817 & 2,817 \\
\hline -2loglikelihood & $-3,907.88$ & $-3,867.25$ & $-2,140.05$ & $-2,105.69$ & $-1,675.34$ & $-1,649.89$ & -914.46 & -893.31 \\
\hline $\mathrm{R}$-squared & 0.46 & 0.46 & 0.50 & 0.48 & 0.65 & 0.66 & 0.68 & 0.68 \\
\hline
\end{tabular}

Entries are logit coefficients from multilevel logit models of party choice with first-mentioned party as reference category and standard errors in parentheses $*$ * $<0.05 ; * *$

$p<0.01 ; * * *<0.001$. See Tables A2-A5 in online appendix for full documentation. Source: Danish Election Studies 1971-2011, CMP data and Danish Policy Agenda Project. 
Fig. 1 Issue salience among Danish elite: Difference economic - cultural issues, 1968-2015.

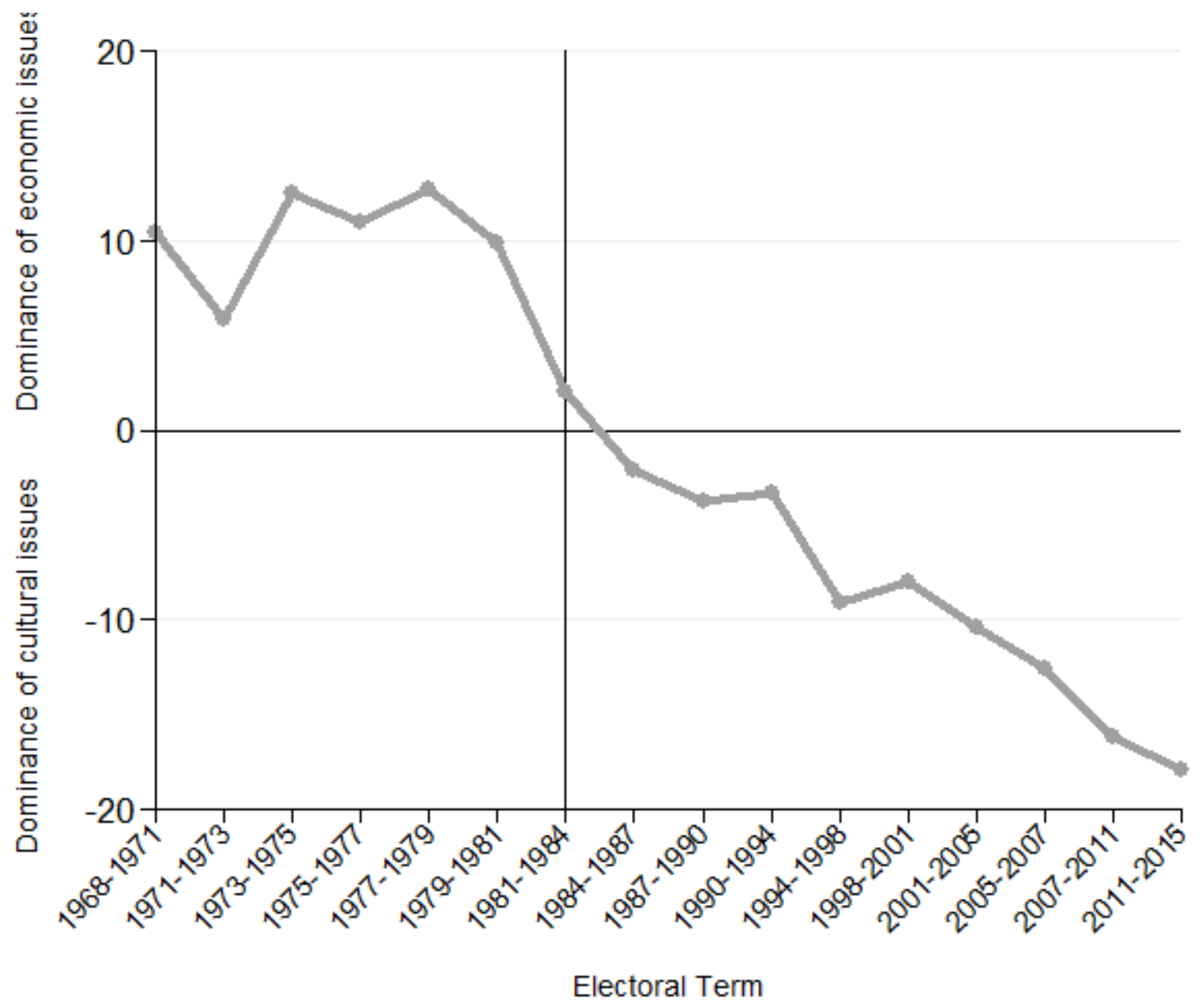

Source: Own calculations based on Danish Policy Agenda Project. 
Fig. 2 Polarization of Danish parties on economic issues, 1968-2011.

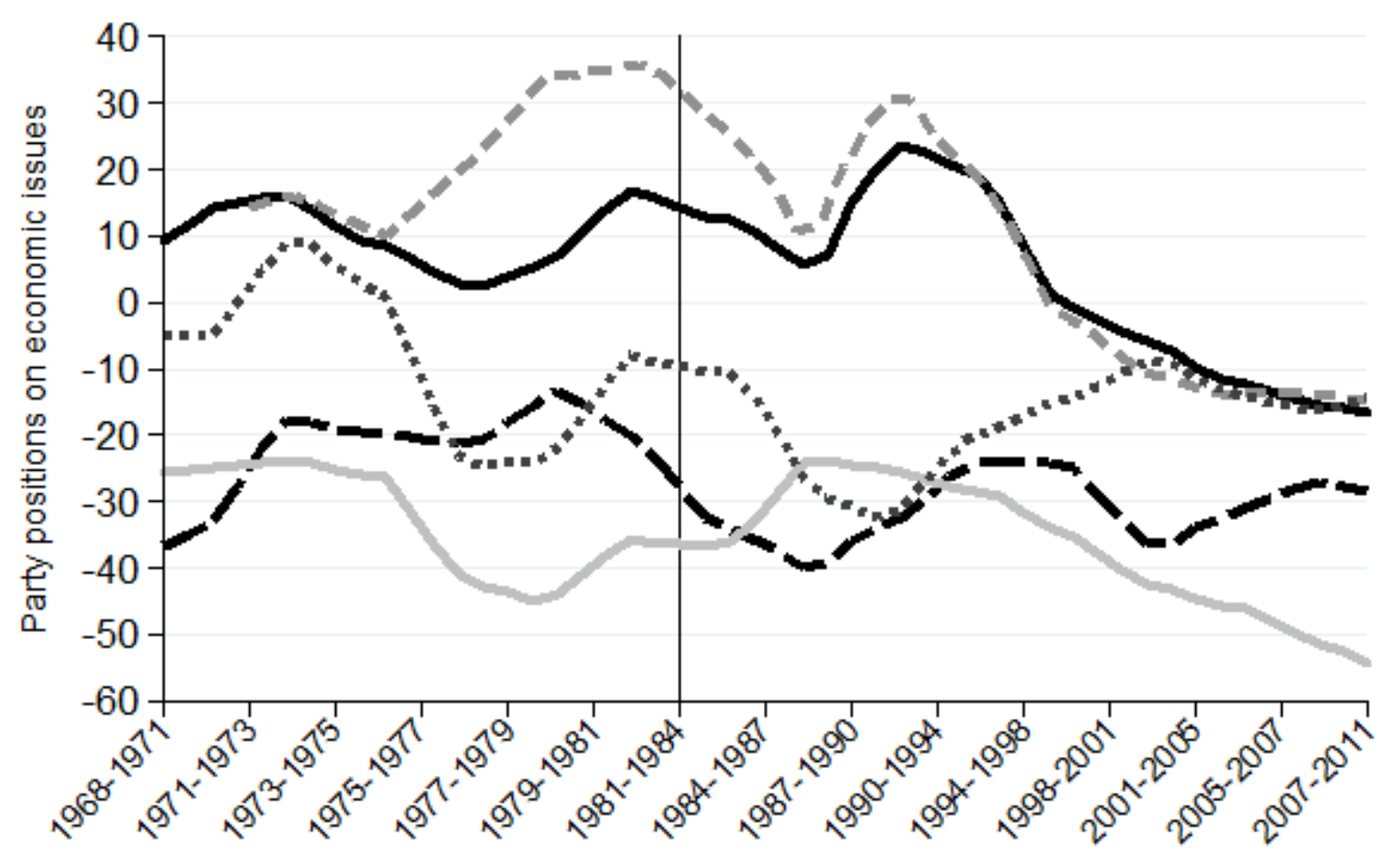

Electoral Term

Party

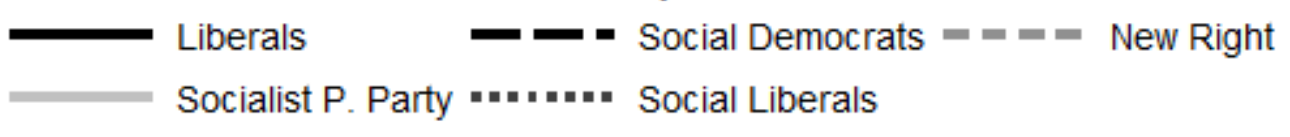

Note: Lines are smoothed. Source: Own calculations based on Comparative Manifesto Project. 
Fig. 3 Polarization of Danish parties on cultural issues, 1968-2011.

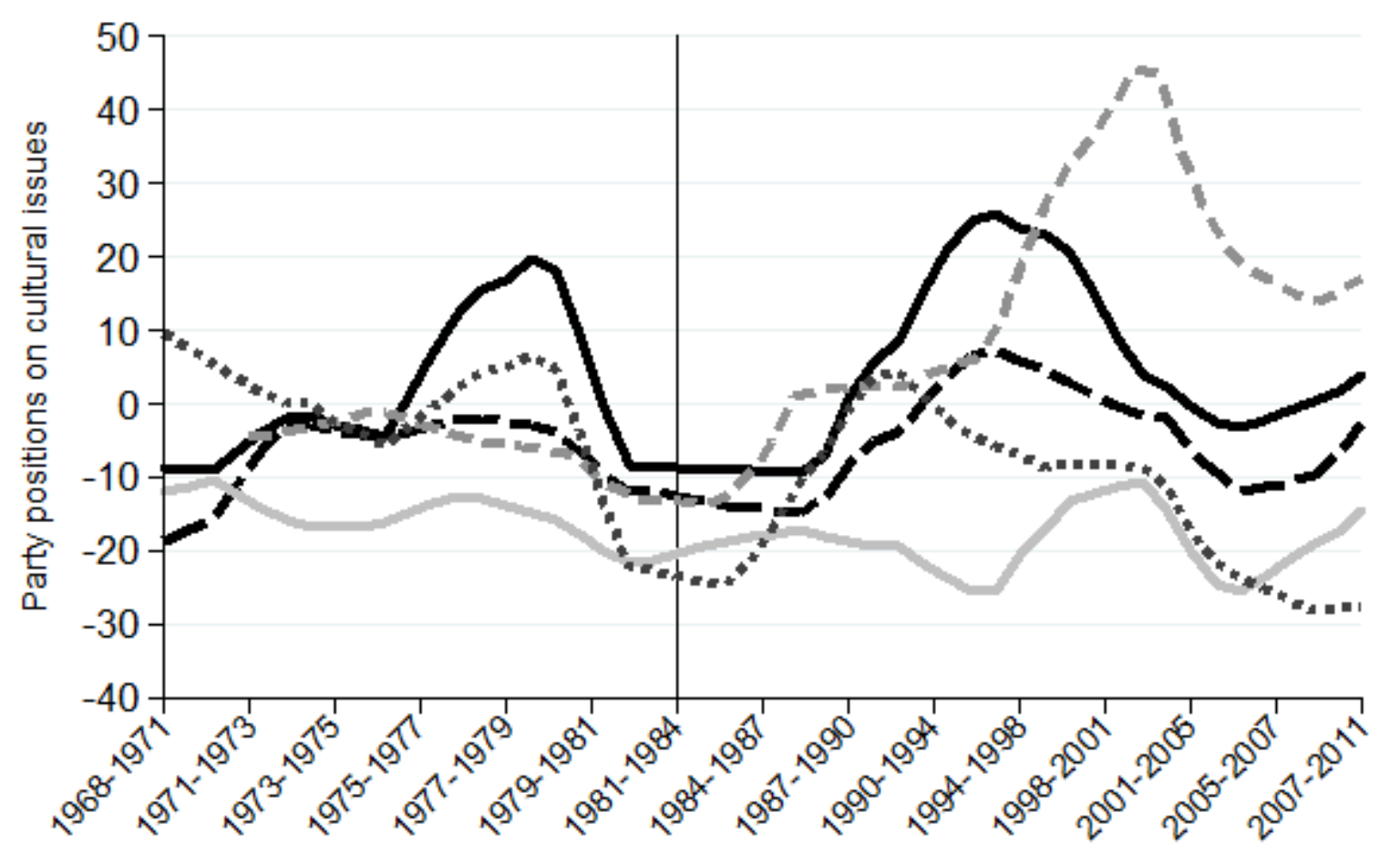

Electoral Term

Party

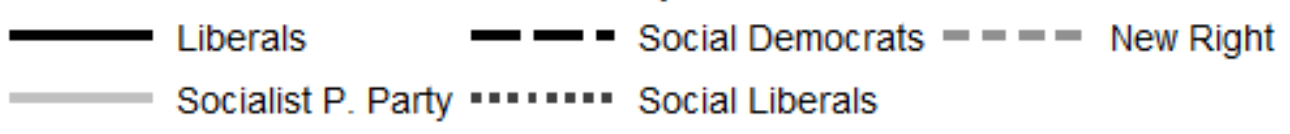

Note: Lines are smoothed. Source: Own calculations based on Comparative Manifesto Project. 
Fig. 4 Marginal effects of economic liberalism and cultural conservatism on party choice over salience of economic and cultural issues among the elite.

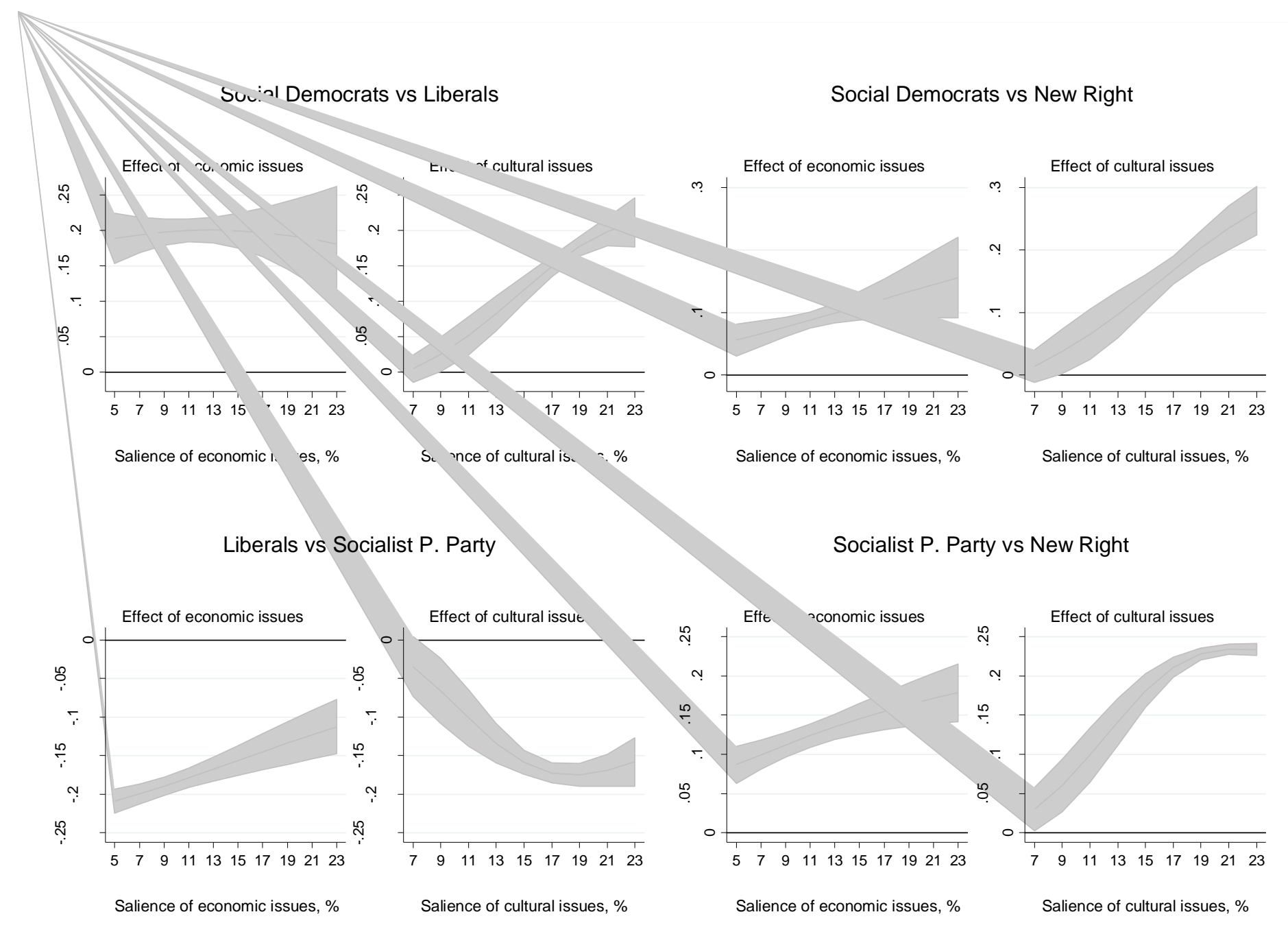

Note: The marginal effects are calculated based on M1a-M4b from Table 1 and Tables A2-A5 in the online appendix. Positive values indicate a higher probability to vote the second-mentioned party for each party contrast. 
Fig. 5 Marginal effects of cultural conservatism on realignment with New Right over mainstream and niche party polarization.

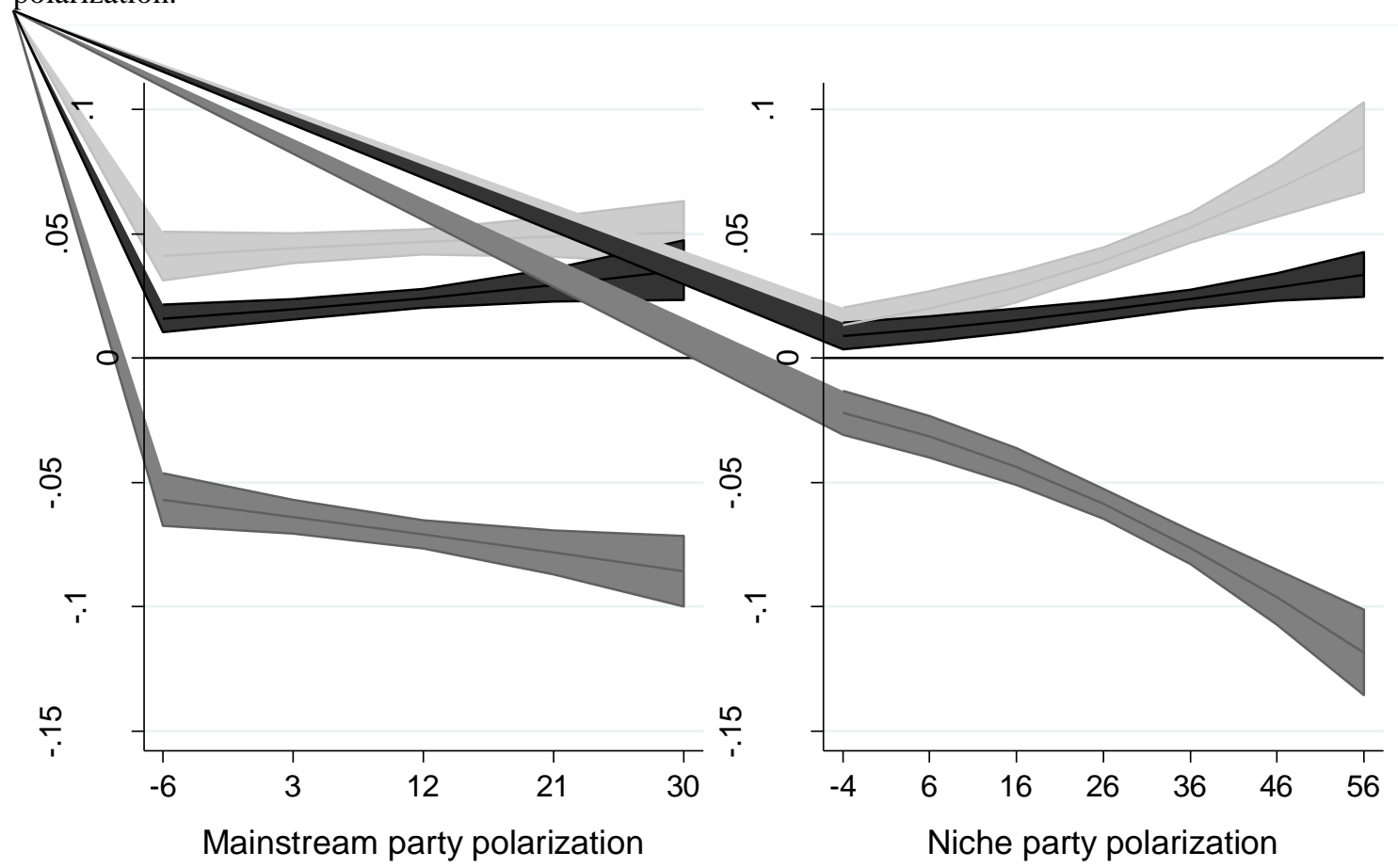

\section{Marginal effect of cultural conservatism on realignment

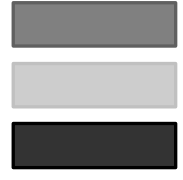 \\ Did not realign with New Right \\ Stayed with New Right \\ Realigned with New Right}

Note: The marginal effects are calculated based on M5 from Table A6 in the online appendix. 
Fig. 6 Marginal effects of cultural conservatism on realignment with left/right bloc over mainstream and niche party polarization.

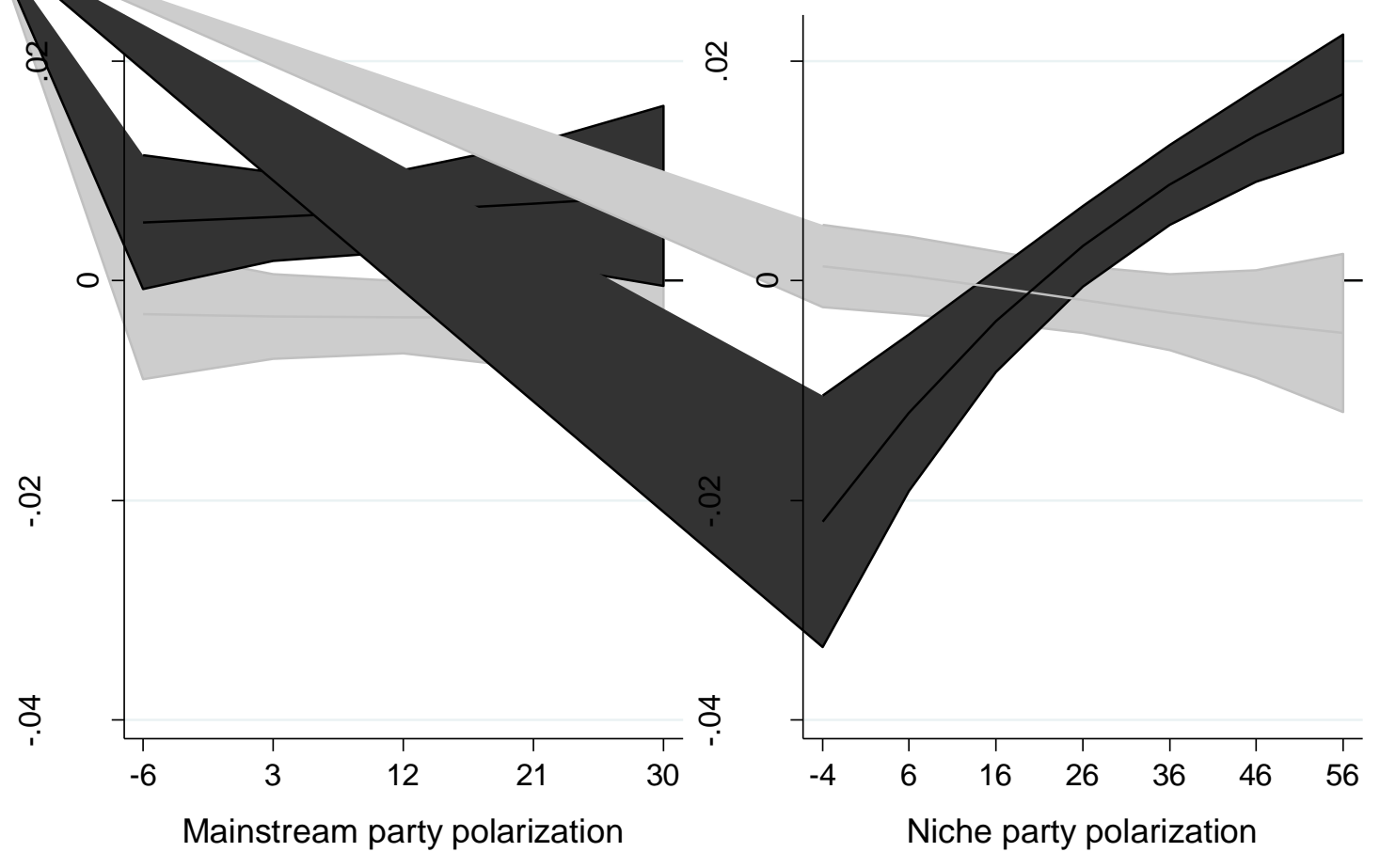

\section{Marginal effect of cultural conservatism on realignment}

Realigned with left bloc

Realigned with right bloc

Note: The marginal effects are calculated based on M6 from Table A7 in the online appendix. 